\title{
Water Purification System Device
}

National Cancer Institute

\section{Source}

National Cancer Institute. Water Purification System Device. NCI Thesaurus. Code C50315.

A system designed to remove unwanted substances from water. 